\title{
The Myth of the Peasant in the Global Organic Farming Movement
}

\author{
GREGOR Y A. B ARTON* \\ E-mail: g.barton@westernsydney.edu.au
}

\begin{abstract}
Organic farming activists have promoted the idea that ancient peasant wisdom informed the basic principles or Albert Howard's Indore method, and of organic farming generally. The myth of the peasant origins of organic farming has influenced environmental activists and historians alike and concealed the remarkable contributions of Albert Howard and his first and second wives, Gabrielle and Louise Howard. A few statements made by Howard himself, and by his second wife, Louise, inspired the myth of peasant origins of organic wisdom. But a closer look at the published and unpublished writings of the Howards show that the formulation of the Indore method, which lies at the heart of organic farming, is a strict scientific protocol with its roots in the scientific work of Albert Howard and his cohorts.
\end{abstract}

Keywords: organic farming, peasants, agricultural history, Albert Howard, environmentalism.

Organic farming draws upon scientific arguments that arose as a cultural reaction against the perceived moral and physical degeneration brought about by industrialization and capitalism. ${ }^{1}$ During the first half of the twentieth century, many of the basic tenets of organic farming developed in response to an extended period of industrialization, imperialism, wars, decolonization, and globalization. To its first adherents, organic farming offered not merely a model for agriculture; it proposed a new model for humans to relate to nature, one that sought harmony with natural processes. Many of the basic tenets of environmentalism developed in tandem, and even out of, the early stages of organic farming, and constitute a middle stage of the environmental movement, between global conservation and global environmentalism. Organic farming enthusiasts have persistently identified peasants as a conduit for knowledge and ancient wisdom that moderns have forgotten or abandoned. The myth of the peasant origins of organic farming has therefore shaped the perception of generations of environmental activists and historians alike and concealed the remarkable accomplishment of the founders of organic farming, Albert Howard and his first and second wives, Gabrielle and Louise Howard, respectively. 
Contemporary historians have absorbed and repeated the myth of the peasant as a fountainhead of organic wisdom. Philip Conford in The Origins of the Organic Movement (2001) and The Development of the Organic Network: Linking People and Themes, 1945-95 (2011) offers an uncritical account of this prevailing myth as does William Lockeretz in Organic Farming - An International History (2007). William Beinart and Lotte Hughes published an important discussion on organic farming in Environment and Empire (2007). The authors provide an excellent case study with Albert Howard but do not challenge Conford and Lockeretz belief that Howard arrived at his organic protocols by observing peasant agriculture. ${ }^{2}$

Albert Howard established the protocols of organic composting while working as a botanist for the Imperial Agricultural Research Institute (IARI) in British India from 1905 to 1935. Lord Curzon, Viceroy of India, established the IARI to forge a central research organization that would increase agricultural productivity in India, where farming was the largest and most important industry. In this context Howard, working with colleagues at Pusa in the state of Bihar, produced the "Indore" compost method that served, and still serves, as the core of the organic farming movement. Upon his retirement from India in 1930, Howard wrote a series of popular books that emphasized - in a way not found in his earlier scientific publications - the wisdom of the East and the lessons he learned from Indian peasants, whom he dubbed "my professors." 3 Alongside the Indore method of composting, his followers have consistently asserted that the organic farming movement, through its central founding figure, Albert Howard, repackaged indigenous peasant knowledge for a modern scientific world.

While a careful comparison of his earlier and latter books reveals clues to this shift, a number of factors explain why scholars and enthusiasts have accepted at face value the peasant origin of organic farming. The papers of Sir Albert Howard were missing and scholars had been left with, instead of diaries, letters, and early reports from his professional work, only his published books, including his later works that mix science, mysticism, and romanticism. His second wife, Louise, wrote the only biography of Howard, but she had not shared with Howard (as did Gabrielle) his early critical years in India, when he developed the Indore process that produced the Indore method. ${ }^{4}$ Finally, the appeal of the peasant myth influenced almost all the followers of organic farming, including scholars who themselves admire organic farming, and who have had little reason either to question the founding myths of a movement they admire or to question the hagiography lovingly established by Louise. ${ }^{5}$

The author bases this article on the recently discovered papers of Albert, Gabrielle, and Louise Howard. ${ }^{6}$ These sources include the letters and papers of his first wife, Gabrielle, who laboured at his side in India, as well as the massive archive of letters, newsletters, and reports collected by his second wife, Louise. The collection sheds new light on the origins and the early years of the organic farming movement, from its beginning in the early twentieth century until the late 1960s. In particular, the separation of the organic farming protocols and the myth of peasant tutelage throws the accomplishments of Albert Howard, Gabrielle Howard, and most especially 
Louise Howard, into clearer historical light-accomplishments that not only reveal the often hidden role of women in science, but the remarkable accomplishment of three people who changed land use, consumer habits, and ideas around the globe.

Scholars have done little historiographical work on the organic farming movement. ${ }^{7}$ This is surprising given the developed state of environmental history and the formative role that the organic farming movement has played in the environmental movement. Historians of science have shied away from a movement that mixes science and spiritualism, often in equal measure. However, one book offers the national history of organic farming in Britain. Philip Conford's encyclopedic The Origins of the Organic Movement makes little effort to engage in the historiography, and rather offers an interesting potpourri of bibliographical references and themes. Yet the book misses most of the development of the movement outside Britain and offers no global analysis; nor does it place the movement analytically within the environmental movement as a whole. William Lockeretz in Organic Farming: An International History edited a volume that focused on the period from the 1980s to the present. The authors traced the "second generation" of organic activists - their success in gaining government support, engaging mainstream scientists, and forming effective international organizations. The contributions cover the early movement in summary form, and focus heavily on the United States and Europe. The contributions also include chapters by activists who played a part in the movement, and who, like Lockeretz, are not historians by training or practice. Both of these authors, and most particularly Conford, accept at face value the extraction of organic farming protocols from the observations of peasants, particularly those in India. ${ }^{8}$

\section{The Origins of the Organic Farming Protocol}

In 1928, Albert Howard published the founding document of the organic farming movement, The Waste Products of Agriculture, which laid out his original techniques for mixing animal and vegetable waste to restore soil fertility. ${ }^{9}$ Published twelve years later, An Agricultural Testament was a book of quite a different stamp. It drew on the basics of his compost protocols dubbed the "Indore method" and added a prophetic mix of holism, mysticism, and practical knowledge to his earlier work. Abandoning his matter of fact prose style that blended careful scientific analysis with the plain speaking simplicity of a farmer, from this point on Howard wrote with a fiery pen, warning that civilization faced imminent collapse with the rape of the earth's soil by extracting minerals from the land that left the green mantle of the earth a slag heap of dead dirt, devoid of humus, and devoid also of the bacteria, fungi, water, worms, minerals, and air that give life to the soil. Without this living humus, humans harvested plants from the earth that lacked nutrients. This deficiency, he warned, plants passed on to animals, and through them, to ourselves. Even as we consumed ever greater quantities of food, humans simultaneously lived in a state of semi-starvation and suffered from obesity. Humans suffered therefore from modern 
diseases that peasants who lived simply and without industrial farming techniques never experienced.

An Agricultural Testament proved hugely successful and won over to the cause even more converts than Waste Products of Agriculture. A careful comparison of the two texts reveal a shift from a more pragmatic and scientific Howard in his early years, to a more mystical, romantic and philosophical Howard in his later years. Yet the "father of organic farming" had not changed his techniques. Rather, he had appropriated the language and philosophy of his own followers, who wrapped a number of historical myths around the Indore method. Followers of Howard have attached a key romantic myth to Howard's organic protocols: that he arrived in India as a scientist who had to unlearn his formal training and that he humbly discovered the Indore method from the inspirational peasant farmers of rural India. Indeed, Howard made passing reference to this idea in his later years, and his second wife Louise picked up and expounded on these few statements. The myth of the peasant in organic farming has given rise among Howard's followers that he and his two wives bequeathed to the West and a globalizing world not a brilliant new conceptualization and methodology of compost but, rather, the ancient wisdom of the East.

\section{The Search for Premodern Wisdom}

The claim that Eastern wisdom, and peasants in particular, provided the foundations of organic farming grew directly out of orientalism. Scholars employ the term orientalism to denote the literary and artistic depictions of the Middle East and Asia in a manner that sees a wide gulf between the scientific and rational West and a timeless, ancient, and static East: an Asia that cradles a treasure trove of lost knowledge and human experience preserved as if in amber from ancient times to the present. The praise that orientalists paid to the peasant and to the East also contained a left-handed compliment and reflected the sentiments of many imperialists, such as Lord Cromer, consul general (and effective governor) of Egypt from 1883 to 1907, who stated that "the mind of the oriental . . like his picturesque streets, is eminently wanting in symmetry. His reasoning is of the most slipshod description ... deficient in the logical faculty." 10

For many orientalists, Asians exhibited a close-to-nature ethic that more than balanced their non-Western mental makeup. Asians moved with the rhythm of the seasons; possessed exotic faith traditions; preserved ancient agricultural customs; and harboured medical wisdom that had slowly amalgamated over generations of human experience that acted as a conduit from the ancient to the modern and that had not been corrupted by modernity. All this wisdom, Westerners could discover in the Orient, if only they looked for it.

Scholars have debated whether orientalists genuinely admired the East. Literary historian Edward Said viewed orientalism as a "certain will or intention to understand, in some cases to control, manipulate, even to incorporate, what is a manifestly different (or alternative and novel) world."11 Others, however, understood 
orientalism as the inevitable result of globalization and felt that orientalists have often expressed a sincere appreciation of non-Western cultures, to the point of transcribing and rescuing non-Western culture from destruction by salvaging traditions on the verge of extinction through translation, oral histories, archaeology, and a wide array of conservation projects. ${ }^{12}$

Westerners have often ascribed to non-Western faiths a plethora of ancient environmental values that stood as a model to emulate. For instance, some scholars of Hinduism have downplayed Hinduism as a faith system and emphasized instead the more universal aspects of Hinduism as a philosophy and way of life - an approach that appealed to Western audiences. Further, because high Brahmanism developed a form of monotheism that served as an umbrella to local nature gods, and because the sum of practice and beliefs of Hindu people varied remarkably, scholars easily extracted iconic ideas of nature from its wide pantheon of deities and practices. ${ }^{13}$ The same can be said for Buddhism, which in the Theravada system practiced in South and South East Asia, exhibited a syncretism that absorbs local spirits, gods, and myths. The more intellectualized Mahayana Buddhism practiced in East Asia also offered a multitude of schools and approaches to nature that mixed with indigenous faith systems, such as Shintoism and Zen Buddhism. Orientalists have been tempted to read into these varied systems new ideas of recent origin, but wrapped in an ancient and mystical halo. Unlike Christianity, Judaism, and Islam, Hinduism and Buddhism do not offer a single text or even an agreed upon canon. Nor do they have a central organization or an "orthodox" creed. Therefore, Eastern faith systems appeared plastic and amorphous and allowed Westerners to stamp onto the East any number of useful ideas. ${ }^{14}$

The transcendentalist tradition in the United States had long drawn inspiration from Hinduism, creating its own version of the mystical East that, while misreading and misunderstanding Hinduism, promoted an American fantasy of Eastern culture as a treasure house of mysticism that could unloose the human potential for universal brotherhood. Emerson and Thoreau spoke about nature and its immutable laws in a language that organic farming enthusiasts clearly mimicked. They also expressed a profound scepticism of science and all forms of logic chopping, advocating empirical observation and practical experience over abstractions. ${ }^{15}$

Contemporary with the rise of English romantic farm literature in the 1920s and 1930s, many in the British Empire also wrote home about their experiences abroad. In the late nineteenth and early twentieth centuries, Rudyard Kipling cast India as a storehouse of wonder and mysticism, thus prompting a renewed fascination with the Indian empire and native life in particular. ${ }^{16}$ But it was Rabindranath Tagore in particular who put the East before European and American audiences. A Western-educated Bengali poet, Tagore presented a version of the East influenced heavily by Western orientalism. His accolades in the press, the academy, and a Nobel Prize illustrated the rewards that awaited those who could translate the simple virtues of the East to Western audiences. Tagore studied agriculture at the University of Illinois, Urbana, and-like Gandhi-deeply imbibed organic farming and romantic farming literature that 
advocated peasant crafts and virtues. With the advent of World War I, he lectured English and American audiences that the West would need the "sacred water" of India "to sweeten the history of man into purity." 17 That a number of early environmental activists, including those promoting organic farming, ascribed environmental ethics to Hinduism and above all to the peasants of India is not a surprise. ${ }^{18}$

\section{Peasants of the Far East}

The right-of-centre cultural milieu of organic farming circles encouraged enthusiasts to romanticize the peasant. Conservatives in the 1920s and 1930s often contended that a people (volk) carried wisdom and indigenous knowledge from generation to generation. In continental Europe, this notion sprang from the ideas of the German philosopher and historian Johann Gottfried von Herder. During the Napoleonic occupation, von Herder resisted enlightenment reforms and rationalization of laws and customs by arguing that societies thrive on the characteristics of a particular people, and that law should not be universal across cultures and societies. Rather, governments and laws (and elites) should share the racial and cultural characteristics of the people they ruled. Napoleonic reforms, he believed, bred a sterile cosmopolitan culture that divorced people from the soil that nourished them. Universalism destroyed national culture. ${ }^{19}$

Marxists, in particular, found Herder's approach anathema, not only because of the urban base for the "vanguard" of intellectuals who pushed for revolution, but also because in his analysis of Napoleon III Karl Marx had specifically identified the "reactionary peasant" as a backward force in society. The organic farming movement arose in a milieu of resistance to a number of modernizing forces: unbridled capitalism, urban consumer society, and international socialism, all of which arose - at least partially - out of the ideals of the French enlightenment and a belief in the mass perfectibility of society. The myth of peasant wisdom has proved, and still proves, a powerful tool in attempts to resist globalization and dominant consumerist culture by organic activists and their allies in the health food and slow food movements. ${ }^{20}$

F. H. King's hugely influential Farmers of Forty Centuries (1911) inspired many agricultural reformers, including Howard. The imaginative influence of this book cannot be overstated. Howard often referred to it, as did romantic writers on the peasantry such as Robert McCarrison, G. T. Wrench, and many others. King taught and researched agricultural science at the University of Wisconsin in Madison, and then served as chief of the division of soil management in the United States Department of Agriculture Bureau of Soils. ${ }^{21}$ He launched a whirlwind tour of Japan and China and wrote his book in a white heat of unrestrained enthusiasm. He argued that Asia had maintained soil fertility for thousands of years by returning nutrients to the soil - most particularly human waste — and that Western nations ought to adopt this method to preserve soil fertility for the long haul. This book, more than any other single document, popularized the belief in romantic farm literature that peasant wisdom held the key to fight soil erosion and low agricultural productivity. ${ }^{22}$ 
King differed in many ways from organic farming in his prescriptions, however, and organic farming enthusiasts overlooked many glaring holes in his argument. He emphasized not the result of human health, but efficiency. Unlike the conservationists of his day, he saw the need to return nutrients to the soil as a way of using land even more intensively, and for accelerating economic and population growth. He disembarked from his boat in Asia determined to prove his thesis. Where he imbibed his orientalist romanticism is not known, and a biography of his life would prove useful in this regard. While he took many photographs, he also utilized staged photographs of romanticized and idealized peasants. He saw Chinese culture as both ancient and unified, stretching from the misty beginnings of human history to the present, seemingly unaware of famines, upheavals, alien rule, importation of technology, or changing agricultural methods. He entirely overlooked the problems of massive deforestation and environmental damage. Rather he concluded that the agricultural practices he witnessed produced, among the Chinese, "a race which, with fortitude and rare wisdom, has kept alive the seeds of manhood and nourished them into such sturdy stock.",23

King's argument that Western nations should return night soil from the cities back to the farms appeared to have been formed well before his trip to the far East and to be derived from American, British, and European efforts to address soil fertility. Politicians and engineers have long recommended the use of night soil and the idea has a varied history that dates from the mid-nineteenth century, well before the publication of his book in $1911 .{ }^{24} \mathrm{King}$ also mentioned, without deeper examination, that it was the international settlement in Shanghai - and not Chinese peasants - that arranged for the sale of urban waste to fertilizer middlemen, who in turn delivered night soil from the cities to the farms. Further, King drew heavily on European scientific literature to discuss the advantages of composting methods, through which he viewed Chinese efforts. Thus, King viewed China through a distinctly Western lens. In fact, he entirely missed the fact that China was industrializing so rapidly that the importation of artificial fertilizers had already begun to change agricultural use in the same way that it had in Europe and the United States. Merely touring and identifying composting in a peasant population in the Far East did no more to roll back modernization of agriculture in China than European composting had in Europe. He also paid scant attention to the poverty that such labour-intensive methods produced. He lingered long in his book over foot pumps and labourintensive hand tools, revealing a deep romanticism about medieval rural life that contributed little to subsequent organic farming.

Broad cultural influences, like orientalism or rural romanticism, did not flow in a unidirectional fashion. The Roosevelt administration, National Socialists, Communists, Japanese fascists, Mongolian princes, Manchurian warlords, along with religious spiritualists such as Theosophists, agriculturalists like the followers of Rudolf Steiner, and utopian novelists all fantasized about the potential of the treasure house of Eastern wisdom. But this mutual fascination did not produce similar outcomes. Henry A. Wallace, Secretary of Agriculture (and later vice president) under Franklin D. Roosevelt shared King's interest in a mystical far East. After flirting with 
Theosophy, he sponsored a 1945-46 expedition to search for arid plant hybrids from the Gobi Desert, particularly to find strains of wheat that could be transplanted to the American Great Plains - a particular concern given the dust bowl experience of the 1930s. Wallace and the Soviets, whom he admired, pursued scientific farming, productivity, and hybrids. Even the East dreamed about the East, as all regions and nations romanticize the past and put powerful images to utilitarian use. ${ }^{25}$

Organic farmers joined a wide array of individuals who claimed inspiration from Eastern wisdom. Myth does not equate with ignorance but rather is a narrative, an imaginative story that combines history with romanticism, mysticism, and subjective values. Given the streams of romanticism, orientalism, and holism that inspired Howard's imagination, it made sense that he made a number of passing references about peasant wisdom. It also made sense that the organic farming movement seized on these statements, and that the only biography of Howard, written by Louise, drew attention to the peasant wisdom of the East that illuminated and justified Howard's accomplishments.

\section{The Prime Case Study: The Hunzas}

The myth of the peasant in the organic farming movement clearly overlapped with the Enlightenment ideal of the "noble savage." In many ways, the concept of the noble savage parallelled the idealization of Eastern cultures, particularly among Europeans who put their imaginative stamp on hunter-gatherer societies, and on societies left relatively untouched by modernism. The discovery of the Americas and the islands of Oceania gave rise to numerous accounts of native people and inspired both John Hobbes's theory of human brutality and savagery in Leviathan and Rousseau's image of utopian societies that boasted free love, peaceful coexistence with nature, and communal property. ${ }^{26}$

Organic farming drew on its own version of the noble savage with the Hunzas. Enthusiasts held up the Hunzas as the prime example of wholesome peasants who over eons preserved a primitive agriculture unaffected by modern mechanism, fertilizers, or pesticides. The Hunzas - the Barusho people - still live in the Hunza Valley in the Karakorum Mountains in northern Pakistan, in the western Himalayas. They claim descent from the soldiers of Alexander who invaded Northwest India in the fourth century BC, and as Ismaili Muslims they practice a branch of the Shia faith and may be related genetically to Roma gypsies. Albert Howard refers to the Hunzas as a people who enjoyed spectacular health because their food came from exceptionally fertile soil. He never worked with the Hunza, nor did he conduct experiments with them. But he did draw inspiration from them, primarily by reading the accounts of other authors. ${ }^{27}$ Drawing on the popular romantic farm literature of G. T. Wrench (also a medical doctor) Howard wrote that

In the Hunzas living in a high mountain valley of the Gilgit Agency on the Indian frontier we have an exciting demonstration of what a primitive system of agriculture can do if the basic laws of Nature are faithfully followed. The Hunzas are described as 
far surpassing in health and strength the inhabitants of most other countries; a Hunza can walk across the mountains to Gilgit sixty miles away, transact his business, and return forthwith without feeling unduly fatigued. ... [F]or thousands of years they have evolved a system of farming which is perfect. ${ }^{28}$

The Hunza example fulfilled the requirements of a movement that sought scientific validity for an ideal example of health that emanated from the application of organic protocols. Howard quoted favourably from the reports of a British medical officer in India, Robert McCarrison who claimed that "During the period of my association with these people I never saw a case of asthenic dyspepsia, of gastric or duodenal ulcer, of appendicitis, of mucous colitis, of cancer." 29

The secret of the Hunzas? Howard suggested a form of organic composting that mixed "vegetable, animal and human wastes . . . carefully returned to the soil." 30 Wrench, whom Howard read and cited profusely after his career in India, summed up the peasant mystique that many in the organic farming movement shared. The Hunzas formed "an erratic block of an ancient world, still perhaps with its peculiar knowledge and traditions, and preserved in that profound cleft of theirs from the decay of time.... Everything suggests that in its remoteness it may preserve from the distant past, things that the modern world has forgotten and does not any longer understand. And among those things are perfect physique and health."31

Wrench elsewhere argued that the Hindu doctrine of the migration of the soul gave a spiritual reflection of the organic farming "law of return." Just as the soul returns again and again, so, too, do nutrients return to the soil. No wonder, he concluded, that Howard discovered the protocols of organic farming on Indian soil. ${ }^{32}$

In this regard the Hunza example ran parallel to the fascination in this period with a myth common throughout central and eastern Asia of the "Shambhala" valley, which served as a reservoir of wisdom, long life, and perfect health. Various Hindu and Buddhist sources described this myth. It first caught the attention of the early Portuguese explorers, as well as, later, British, Soviet, National Socialist, and American enthusiasts. Echoing the Hunza example, Shambhala inspired James Hilton's 1933 novel, Lost Horizon, about a land that time forgot called Shangri-La. Influenced by Hilton's novel, Franklin Roosevelt bestowed the name Shangri-La on the presidential retreat later named "Camp David." 33 As the imaginative appeal of this legend illustrates, organic farming enthusiasts joined a wide array of individuals and groups that promoted strains of Eastern wisdom overlooked by the West. ${ }^{34}$

\section{Gabrielle and Louise Howard}

The letters of Howard's first wife, Gabrielle, shed substantial light on the question of whether, or to what degree, Howard was influenced by peasant agricultural practice. Gabrielle's extensive letters home to her mother, who resided in England reveal no sign of a particular regard for peasants. The letters present a uniformity of views between Gabrielle and Albert, who worked side by side during their time in India. Mostly undated, the correspondence is held in a private archive by the Matthaei 
family and range between 1913 and 1929. They reveal that Albert Howard did not develop his Indore compost method as a remedy for industrial agriculture or from a desire to base agriculture on natural principles. More important, they show that Howard did not arrive at his principles of organic farming via peasant wisdom. The Howards shared a view of the peasantry that, though by no means negative, exhibited no hint of learning from the bottom up, nor even a modicum of romanticism about peasant farming techniques. They both approached their work strictly in the spirit of scientific observation and experimentation.

Gabrielle refers frequently to touring farmland, and general observations of life and culture in British India, and of what they perceived to be Indian incompetence. Just a few examples give an idea of how she and Albert approached the peasantry. For instance, Gabrielle explained the exasperation of seeing railway workers attempt to pin stickers on their luggage. When nothing else would work, she saw them attempting to attach the label with the juice of "a half eaten mango." ${ }^{35}$ She found the Indian peasants in some districts to be living in "indescribably dirty huts" and she attributed their good health to constant bathing and the powerful Indian sun. ${ }^{36}$

They toured farmland extensively throughout India, and never mentioned peasant innovations or traditional practice that interested her. She states, typically, "We went all over the farm which was very interesting as it was in a district with a type of agriculture we had not yet seen - the cultivators are said to be the laziest set in India but they seemed exceedingly friendly and good natured. They had very curious shoes." ${ }^{37}$

At one unidentified monastery in the foothills of the Himalayas, their guide introduced them to a prayer wheel with slips of paper attached that read "Om Man I Padme Hum," which the guide interpreted to the Howards as "Praise to the jewel in the Lotus." Each turn of the wheel counted as a repetition of the prayer. An old woman laboriously turned the six-foot high prayer wheel. Gabrielle tells humorously how, "Bert was all for having a motor engine fixed up to whizz the wheel round continuously until he found out that it must go slowly to be efficacious." She interprets to her mother that the prayer wheel was "Buddhistic ... nothing to do with the Koran which is Mohammedan." ${ }^{38}$ Reading through the hundreds of letters one does not gain from the Howards a deep sense of either Christian or other religious sentiment, and no sense of a profound regard for tradition. Rather one senses at best a mere passing cultural interest.

However, the Howards did have a deep interest in agriculture and they pursued this passion with their scientific experiments and efforts to spread the results of their work throughout India. ${ }^{39}$ After many years working at Pusa, Howard gained funding for his own Indore Research Station in 1924. Unfortunately, this work came to fruition only as Gabrielle neared the end of her life, stricken by an aggressive cancer. Her health had been rumoured to be bad, because she remarked at a conference, that "It has at any rate shown the committee that I am still alive and kicking." 40

Gabriele explained how she and Albert hosted conferences and exhibitions, which went "very much better that I could have dreamed possible." She noted with great satisfaction that telegraphs kept raining in "demanding more accommodation, 
with local hotels full, rest houses full, and with huts erected in gardens, people sleeping in the offices and six visitors in their own bungalow." ${ }^{41}$ A few quotes illustrate how she and Albert worked extensively to educate peasant farmers, along with other British imperial officials. "We had not only 40 members of the cotton committee, 7 cotton committee clerks, 22 state officials and various clerks brought by the visitors and over 400 peasants all to be accommodated simultaneously and taken to and from by motors. . . The servants managed excellently except the [illegible] who got drunk." ${ }^{, 2}$ She also spoke at the meetings. This amazed the visitors "who I suppose had not heard a woman speak before." ${ }^{\text {"43 }}$ By the date of this conference, the Indore method had become fixed as a protocol, which her letters reveal. ${ }^{44}$

The Howards taught the peasants directly at the institute, housed in a camp "at the gate of the institute" and with help from the "Indore Fire Brigade" and " 12 boys scouts to help the peasants." They also had some basic films made, which appear now to be lost. She remarked that cinema was "part of the teaching." 45 Her letters do not indicate anywhere that either she or Albert Howard learned from the peasants. Rather, they conducted scientific experiments, and passed the results on to the other agricultural experts, scientists, farmers, and then to Indian peasants.

After Gabrielle's death, Albert Howard retired from service in India, returned to Britain, and married her sister Louise, whose writings present a picture of Albert in India that read back into the past an Howard with fully developed ideas on organic farming. She revealed a one-man show of brilliance, bravery, and audacity at almost every turn, her biography reading rather typically like a family memoir full of loving exaggeration that downplays his colleagues and the institution that employed him. ${ }^{46}$ Having never visited India, Louise simply could not accurately describe the institutions where he served nor the vast teamwork involved in imperial agriculture. She missed key works, book reviewers, and other writings by his colleagues that show concern for non-chemical fertilizer. She also overlooked the hard-headed and utilitarian economic policy that inspired most of Howard's work and that of his colleagues ${ }^{47}$ Scholars and organic farming enthusiasts derive their widespread belief that Albert Howard learned his Indore Method from peasant wisdom from a selective sampling of only a very few sentences from Louise Howard.

[It is] because he worked away from Western agriculture that Sir Albert gained that enormously wide understanding. ${ }^{48}$

He considered that fortune had apportioned to him an exceptional favor in putting him to work among the peasants of the East. ${ }^{49}$

His demonstration that the female hops of commerce could not be cultivated without the presence of the male plant alongside was an example of an instinctive awareness of the importance of natural principle. ${ }^{50}$

More especially did he acknowledge the lessons to be got from the century-old experience of the Indian peasants, whom in later life he most happily named his "professors." 51

These few statements form the core of the myth of the peasant origins for Albert Howard's work, and scholarship on organic farming and popular culture has cited 
these passages widely. ${ }^{52}$ The question remains: if Albert and Gabrielle Howard did not derive their organic protocols from Indian peasants, where did their ideas originate?

\section{The Un-organic Roots of the Organic Farming Movement}

While Louise indicated that Albert consistently preferred the organic processes found in nature, the writings published during his tenure in India reveal no aversion to artificial fertilizers or pesticides. In 1924, he published Crop Production in India, which represented the culmination of his work with Gabrielle up to this time. ${ }^{53}$ In this, Howard gave only a hint of his future work on compost. He did show a passing familiarity and respect for composting by peasants in China, gleaned from King's book Farmers of Forty Centuries. He remarked however that Indian peasants lagged far behind the composting practices of the Far East. ${ }^{54}$ He then made a pivotal remark that showed the limitation of these practices for India. "The use of human excreta in preparing composts, as practiced in China, is impossible in India." In India, due to the heat and poor transport, human waste spread disease easily. He could have also added that cultural and religious prejudice against the use of human manure, just as in England, made this a more difficult practice to implement. ${ }^{55}$

In The Waste Products of Agriculture (1928) written only seven years before his retirement from India, Howard discussed chemical fertilizers and pesticides without a trace of criticism. It must be kept in mind that this book laid out the complete Indore method in its entirety - the key component of organic farming protocol— and marked the end point of his major scientific research to date. In this book, he recommended the feasibility of using sulphate of ammonia for fertilizer. An important by-product of coal, sulphate of ammonia was easily obtained from the Tata Iron and Steel Company at Jamshedpur and from the coal mines in Bengal, Bihar, and Orissa. He pointed out that "The manner in which this source of supply is being developed is very satisfactory and it is still more satisfactory that a market for increasing quantities of the sulphate of ammonia produced in India is being found in the country." 56

At the same time, he lamented that the high price made this product difficult for the majority of farmers to use. Nitrogenous fertilizers from "the establishment of synthetic process" have been "a matter of the first importance." Further, the cyanamide process "offered the best prospect of success in India" as a method of "obtaining synthetic sulphate of ammonia." But the high price again made this option problematic. He went on to write that "it is also to be hoped that, should the demand for artificial fertilizers in India make it worthwhile, private enterprise will come forward to erect synthetic nitrogen works in this country." 57

He then took a very balanced view of the prospect that artificial fertilizer companies might come into India to set up manufacturing. If financially feasible, he concluded, this would be a good thing. "But we need hardly say that we would welcome the establishment by the two firms mentioned, or by any other fertilizer firms, of their own research stations in India working in the fullest co-operation with 
the agricultural departments, the Indian Tea Association, the Indian Central Cotton Committee and any other bodies interested in the fertilizer question." 58

His main concern continued to revolve around not the safety or damage of industrial agricultural methods but the affordability of artificial fertilizers and pesticides. In this book, he pointed to the fact that he developed the Indore method out of economic necessity, as a way of raising soil fertility that Indian peasants could undertake without the expense of artificial fertilizers or pesticides. He raised only one concern - the bias involved in taking money from corporate interests, such as the Rothamsted Experimental Station in England. Government agencies, he felt, offered the best hope for advancement of agricultural practice in India. He sounded this note early in India, a note picked up by his immediate followers of the Indore method.

Where Howard identified the soils of India as fertile, he did not credit the agency of the peasants themselves. His chapter on "oil seeds" argued that the fixation of nitrogen from the atmosphere kept the Indian soils fertile. He did not mention that Indian peasant methods of fertilization returned nutrients to the soil. "It is sometimes forgotten that the combined nitrogen lost in the shipments of oil-seeds is automatically replaced by fixation of free nitrogen from the atmosphere. If this were not the case, the soil of India would have been exhausted long ago."59

He gave no credit to the agricultural methods of Indian peasants. In fact he indicated that only the "automatically" replaced fixation from the atmosphere restored nitrogen to the soil. He concluded that disease in plants could be fought with pesticides or better selection of breeds and soil aeration. He suggested that copper sulphate made a useful pesticide, but one that the peasant could not afford. His early works make clear that the poverty of the Indian farmers pushed Howard to the Indore method, not his aversion to fertilizers and pesticides.

\section{Conclusion}

The widespread notion among historians of organic farming, and among organic farming enthusiasts, that Albert Howard founded the science of his Indore method on the ancient peasant wisdom of India is clearly a myth. Many factors lay behind the adoption of this idea, not least a few statements made by Howard himself, and his second wife, Louise, in her biography of him. But the persistence of the peasant myth has obscured the startling originality of Albert Howard's work, and of Gabrielle's contributions to the founding of this global movement.

This investigation into the use of peasant wisdom by early proponents of the organic farming movement illustrates a larger point: While often understood in purely scientific terms, organic farming should also be understood as a larger cultural movement. This one aspect of the movement also illustrates how the organic farming movement had global roots that have now become embedded in global culture. It is an idea that arose early in the organic farming movement and has now expanded with the success of the movement to be a ubiquitous part of global culture - the myth of the peasant farmer, who represents ancient knowledge rediscovered by the organic farming movement. 


\section{Bibliography}

\section{Unpublished primary sources}

Letters of Gabrielle Howard to her mother, 1913-29. Private collection held by the Matthaei family, Birmingham, UK.

\section{Secondary sources}

Barton, Gregory A. "Albert Howard and the Decolonization of Science: From the Raj to Organic Farming." In Science and Empire: Knowledge and Networks of Science in the British Empire 1850-1970, edited by Brett Bennett and Joseph Morgan Hodge, 163-186. Basingstoke: Palgrave Macmillan, 2011.

_. "The Appeal of Orientalism." British Scholar 3:1 (2010): 1-4.

Informal Empire and the Rise of One World Culture. Basingstoke: Palgrave Macmillan, 2014.

"Sir Albert Howard and the Forestry Roots of the Organic Farming Movement." Agriculture History 75:2 (Spring. 2001): 168-87.

Beattie, James. "Review of Environment and Empire, by William Beinart and Lotte Hughes." New Zealand Journal of Asian Studies 11:2 (2009): 200.

Beinart, William and Lotte Hughes. Environment and Empire. Oxford: Oxford University Press, 2007.

Berkhofer, Robert. The White Man's Indian: Images of the American Indian from Columbus to the Present. New York: Knopf, 1978.

Boyd, James G. "In Search of Shambhala? Nicholas Roerich's 1934-5 Inner Mongolian Expedition." Inner Asia 14:2 (2012): 260.

Conford, Philip. The Development of the Organic Network: Linking People and Themes, 1945-95. Edinburgh: Floris, 2011.

- Origins of the Organic Movement. Edinburgh: Floris, 2001.

Cromer, Evelyn Baring. Modern Egypt. New York: Macmillan, 1908.

Duara, Prasenjit. “The New Politics of Hinduism.” Wilson Quarterly 15:3 (1991): 42.

Eisenhower, David and Julie Nixon Eisenhower. Going Home to Glory: A Memoir of Life with Dwight David Eisenhower, 1961-1969. New York: Simon and Schuster, 2010.

Francis, Daniel. The Imaginary Indian: The Image of the Indian in Canadian Culture. Vancouver: Arsenal, 1992.

Frye, Joshua. The Origin, Diffusion, and Transformation of "Organic" Agriculture: A Study in Transnational Social Movement Framing and Outcomes. Saarbrucken: VDM Verlag, 2007.

Hay, Stephen N. "Rabindranath Tagore in America." American Quarterly 14:3 (1962): 444-46.

Howard, Albert. An Agricultural Testament. Oxford: Oxford University Press, 1940.

- Crop Production in India: A Critical Survey of its Problems. London: Oxford University Press, 1924.

_. "The People of the Hunza Valley." Newsletter on Compost, supplement no. 9 (June 1944). Private Archive.

—. The Soil and Health: A Study of Organic Agriculture. New York: Devin-Adair, 1947.

Howard, Albert and Yeshwant D Wad. The Waste Products of Agriculture: Their Utilization as Humus. London: Oxford University Press, 1931.

Howard, Louise E. Sir Albert Howard in India. Emmaus: Rodale Press, 1954.

Inden, Ronald. "Orientalist Constructions of India." Modern Asian Studies 20:3 (1986): 401-46. 
Kipling, Rudyard. Kim. London: Macmillan, 1901.

King, F. H. Farmers of Forty Centuries: or, Permanent Agriculture in China, Korea and Japan. Madison: Mrs. F. H. King, 1911.

Lewis, Todd and Kent Bicknel. "The Asian Soul of Transcendentalism." Education About Asia 16:2 (2011): 12-17.

Lockeretz, William. ed. Organic Farming: An International History. Wallingford: CABI, 2007.

Lunn, Eugene. "Cultural Populism and Egalitarian Democracy: Herder and Michelet in the Nineteenth Century." Theory and Society 15 (1986): 479-517.

Marshal, Peter. The British Discovery of Hinduism in the Eighteenth Century. Cambridge: Cambridge University Press, 1970.

McCarisson, Robert. "Faulty Food in Relation to Gastro-Intestinal Disorder." Journal of the American Medical Association 78 (January 7, 1922): 1-8.

O'Connel, Joseph T. "Gaudiya Vaisnava Symbolism of Deliverance from Evil." Journal of the American Oriental Society 93 (1973): 340-343.

Pearce, Roy H. The Savages of America: A Study of the Indian and the Idea of Civilization. Baltimore: Johns Hopkins University Press, 1953.

Rodale, J. I. The Healthy Hunzas. Emmaus: Rodale Press, 1955.

Said, Edward. Orientalism. New York: Pantheon Books, 1978.

Smith, Sherry L. The View from Officers' Row: Army Perceptions of Western Indians. Tucson: University of Arizona Press, 1990.

Tanner, C. B. and R. W. Simonson. "Franklin Hiram King-Pioneer Scientist." Soil Science Society of America Journal 57:1 (1993): 286-292.

Taylor, Renee. Long Suppressed Hunza Health Secrets for Long Life and Happiness. New York: Award Books, 1964.

Thapar, Romila. "Imagined Religious Communities? Ancient History and the Modern Search for a Hindu Identity." Modern Asian Studies 23 (1989): 209-231.

Trachtenberg, Alan. Shades of Hiawatha: Staging Indians, Making Americans, 1880-1930. New York: Hill \& Wang, 2004.

Trägårdh, Lars. "Varieties of Volkish Ideologies: Sweden and Germany 1848-1933." In Language and the Construction of Class Identities: The Struggle for Discursive Power in Social Organisation, Scandinavia and Germany after 1800, edited by Bo Stråth, 25-54. Gothenburg: Gothenburg University, 1990.

Veer, Peter van der. "Introduction." In Orientalism and the Postcolonial Predicament, edited by Carol A. Breckenridge and Peter van der Veer, 1-19. Philadelphia: University of Pennsylvania Press, 1993.

Wines, Richard. Fertilizer in America: From Waste Recycling to Resource Exploitation. Philadelphia: Temple University Press, 1985.

Wrench, G. T. The Restoration of the Peasantries: with Especial Reference to that of India. London: C. W. Daniel, 1939.

\section{Notes}

* Gregory A. Barton is Professor of History at Western Sydney University and Senior Research Associate in the Faculty of Humanities at the University of Johannesburg. Address: Professor Gregory A. Barton, Western Sydney University, School of Humanities and

Communication Arts, Locked Bag 1797 , Penrith, NSW, 2751, Australia. 61 (02) 9772 6322. The author thanks the Matthai family for making private family archives available for this work.

1 The United States Department of Agriculture National Organic Standards 
Board defines organic farming narrowly as "an ecological production management system that promotes and enhances biodiversity, biological cycles and soil biological activity." See National Agricultural Library, https://www.nal.usda. gov/afsic/organic-productionorganic-foodinformation-access-tools, accessed 22 Sep. 2016. See also Gregory A. Barton, "Sir Albert Howard and the Forestry Roots of the Organic Farming Movement," and idem, "Albert Howard and the Decolonization of Science."

2 See Beattie, "Review of Environment and Empire," 200.

3 As quoted in Howard, Sir Albert Howard in India, 17. Albert Howard's popular books include An Agricultural Testament and The Soil and Health: A Study of Organic Agriculture (first published in 1945 as Farming and Gardening for Health or Disease.

4 Howard, Sir Albert Howard in India.

5 Organic farming advocates have almost all accepted the peasant origins of the Indore method. These include leading lights of the movement after Howard's death-Eve Balfour, J. I. Rodale, Frederich Schumacher, and Patrick Holden, to name just a few, as well as scholars like Philip Conford, Stephen R. Gliessman, Martha Rosemeyer, David Arnold, and John Paull.

6 The author thanks the Matthaei Family who currently hold this collection, and their generosity in making it available for this article and a forthcoming book. The author also thanks the genealogical sleuthing of Ina Mae Barton, for locating the extended family members of Gabrielle and Louise Howard, in Birmingham, United Kingdom.

7 The best, short case study to date is found in Beinart and Hughes, Environment and Empire, 206-209.

8 Two books stand out in the field however. In The Origins of the Organic Movement and The Development of the Organic Network, Conford focuses almost exclusively on Britain. Lockeretz concentrates his investigation on policy and the more recent developments of organic farming in Organic Farming: An International History. For a study of the rhetorical strategies of select organic farming activists, see Frye, The Origin, Diffusion, and Transformation of "Organic" Agriculture. An important discussion on the organic farming is found in Beinart and Hughes, Environment and Empire. The authors, however, join Conford and Lockeretz in the understanding that Howard arrived at his organic protocols by observing peasant agriculture. SeeBeattie, "Review of Environment and Empire," 200.

9 Howard and Wad, The Waste Products of Agriculture.

10 Cromer, Modern Egypt, 146.

11 Said, Orientalism, 12.

12 Barton, "The Appeal of Orientalism," 1-4.

13 For further discussion of the definition of Hinduism, see O'Connel, “Gaudiya Vaisnava Symbolism of Deliverance from Evil," 340-3; Thapar, "Imagined Religious Communities?" 224.

14 Duara, "The New Politics of Hinduism," 43.

15 On the Transcendentalist approach to nature, see Lewis and Bicknel, "The Asian Soul of Transcendentalism," 12.

16 See, Kipling, Kim, Rudyard Kipling's only full novel treatment of Indian life.

17 His presentation of the East to the West had little truck however in Japan, where audiences were not receptive to his persona as "wise man of the East." See Hay, "Rabindranath Tagore in America," 444-6.

18 Inden, "Orientalist Constructions of India," 442; Marshal, The British Discovery of Hinduism in the Eighteenth Century, 43-4; Peter van der Veer, "Introduction," 1-23.

19 Barton, Informal Empire and the Rise of One World Culture, 186-88.

20 Tragardh, "Varieties of Volkish Ideologies," 31; Lunn, "Cultural Populism and Egalitarian Democracy," 496.

21 Tanner, and Simonson, "Franklin Hiram King-Pioneer Scientist," 286-92. 
22 King, Farmers of Forty Centuries.

23 Ibid., 50, 67.

24 Wines, Fertilizer in America, 25-30.

25 Wallace had an interest in Eastern mysticism, and played a role persuading Roosevelt to assist in signing the Roerich Peace Pact of April 1935 to protect cultural monuments and artifacts. See Boyd, "In Search of Shambhala?" 260.

26 Pearce, The Savages of America, makes a convincing case that the observation of Native Americans reveals more about the observers than the subject. See also Berkhofer, The White Man's India, and Francis, The Imaginary Indian. Attitudes from the nineteenth century are explored by Smith in The View from Officers' Row and Trachtenberg, Shades of Hiawatha.

27 Howard, The Soil and Health, 11.

28 Ibid., 37.

29 Ibid., 177. Howard took this quote from Robert McCarisson's 1921 Mellon Lecture, "Faulty Food in Relation to Gastro-Intestinal Disorder," 2-4.

30 Howard, The Soil and Health, 177. Howard further lays out his theory on the Hunza in "The People of the Hunza Valley."

31 Conford, Origins of the Organic Movement, 50.

32 Wrench, The Restoration of the Peasantries, 79-80. Many followers of Howard built on this myth, particularly Howard's American disciple, J. I. Rodale, in his book The Healthy Hunzas. Other popular writers followed such as Taylor, Long Suppressed Hunza Health Secrets.

33 Eisenhower, and Eisenhower, Going Home to Glory, 31.

34 Boyd, "In Search of Shambhala?" 260.
35 Letters of Gabrielle Howard, 107-8. Note, most of these letters are undated and have been assigned page numbers by the author. The page numbers indicate the chronological order from earlier to later dates. The date range is between 1913-29.

36 Ibid., 183.

37 Ibid., 139.

38 Ibid., 202.

39 The early efforts of Gabrielle and Albert Howard focused on wheat. Gabrielle remarks that "Our wheats are however doing splendidly all over and the people are very pleased with them. They are sure to spread." Letters, 166.

40 Letters of Gabrielle Howard, 208.

41 Ibid, 207.

42 Ibid.

43 Ibid., 208.

44 Ibid.

45 Ibid., 209.

46 Howard, Sir Albert Howard in India.

47 Barton, "Albert Howard and the Decolonization of Science," 163-86.

48 Howard, Sir Albert Howard in India, 17.

49 Ibid.

50 Ibid., 20.

51 Ibid., 24.

52 Conford, for instance, characterized Howard as "attached to the traditional knowledge of peasant farmers." See Conford, Origins, 66.

53 Howard, Crop Production in India.

54 Ibid., 39.

55 Ibid.

56 Howard, The Waste Products of Agriculture, 88 .

57 Ibid., 89.

58 Ibid.

59 Ibid., 148. 